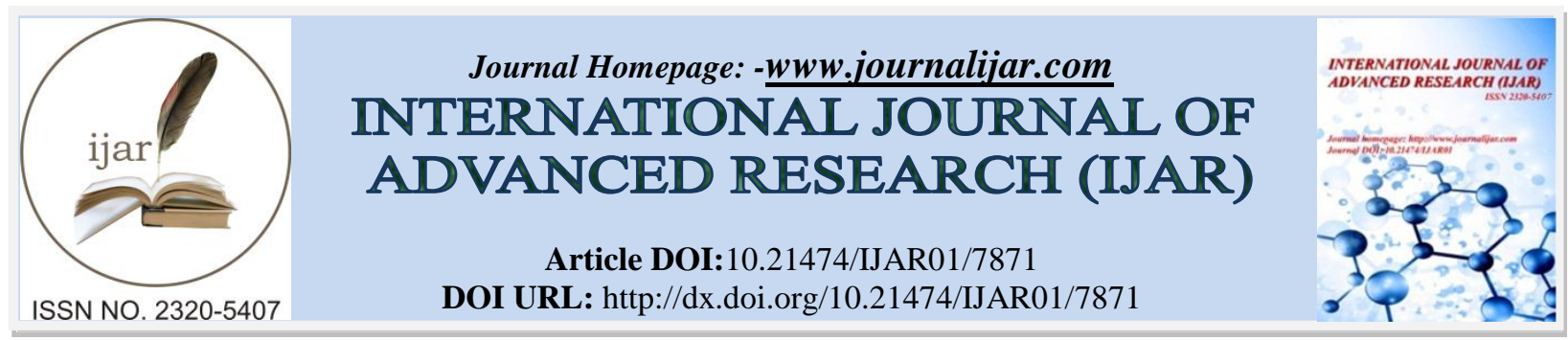

RESEARCH ARTICLE

\title{
FINE NEEDLE ASPIRATION CYTOLOGY OF THE HEAD AND NECK MASSES: ONE YEAR PROSPECTIVE STUDY.
}

\author{
Dr. Swati Arora ${ }^{1}$, Dr. Kuldeep Singh ${ }^{2}$ and Dr. Ravi Kumar ${ }^{1}$. \\ 1. Resident, Department of Pathology, GMC, Jammu,J\&K. \\ 2. Professor, Department of Pathology, GMC, Jammu,J\&K.
}

\section{Manuscript Info}

Manuscript History

Received: 9 August 2018

Final Accepted: 11 September 2018

Published: October 2018

\section{Abstract}

Copy Right, IJAR, 2018,. All rights reserved.

\section{Introduction:-}

Fine needle aspiration cytology is a technique for obtaining cells from a lesion for cytological examination and evaluation. Aspiration cytology was first reported by Kun $\mathbf{M}$ in $1847 .{ }^{21}$ Martin $\mathbf{H}$ introduced this technique in the evaluation of head and neck abnormalties in 1930.In India, fine needle aspiration cytology was first introduced during the early 1970's. FNAC is a procedure where by small amount of tissue or cells is aspirated from a pathological lesion with the help of fine $10 \mathrm{ml}$ disposable syringe of 21,22 or 24 gauge needle. FNAC is an inexpensive, safe and quick procedure and when performed by experienced worker is quite accurate. ${ }^{17}$

In the head and neck region, FNAC is of great value because of the multiplicity of accessible organs and heterogenous pathologies encountered. ${ }^{5}$ Swellings in head and neck region can arise from various structures like lymph node, salivary glands, thyroid, soft tissues, vessels, nerves and being easily accessible, the swellings can be aspirated without difficulty. The present study aimed at studying the spectrum of various lesions presenting in the head and neck region based on cytological findings. This study would assist the surgeons in identifying the common swellings presenting in the head and neck region, selection of the patient for surgery and palliative therapy and also help them in detecting the metastasis and staging of certain tumors.

\section{Materials and method:}

The study was conducted on 900 patients presenting with head and neck swellings over a period of one year $\left(1^{\text {st }}\right.$ November, 2014 to 31st October, 2015) in the Cytology section of Postgraduate department of Pathology, GMC, Jammu. In each case, a brief clinical history and physical examination along with evaluation of relevant investigations was carried out. FNAC was performed by the cytopathologist using $20 \mathrm{ml}$ disposable syringe with 2123 gauge needle attached to the Cameco syringe pistol. One or two smears were fixed in $95 \%$ isopropyl alcohol or ethyl alcohol, stained with papanicolaou(PAP) and others were air dried, stained with May Grunwald Giemsa. Ziehl Neelsen $(\mathrm{ZN})$ staining was performed wherever required. The cytomorphological features of various diseases were studied.

\section{Observations:}

The study included 900 cases among those age ranged from 11 days to 95 years in which $51.44 \%$ were males and $48.56 \%$ were females. Maximum incidences observed in the age group of 21-30 years. Table 1 depicts distribution of swellings according to organ of origin. 
Table I:-Distribution of Swellings According to Organ of Origin

\begin{tabular}{|c|c|c|}
\hline Organ of origin & No. of cases & Percentage \\
\hline Lymph node & 441 & $49.00 \%$ \\
\hline Salivary glands & 67 & $7.45 \%$ \\
\hline Thyroid gland & 175 & $19.44 \%$ \\
\hline Miscellaneous & 217 & $24.11 \%$ \\
\hline Total & 900 & $100.00 \%$ \\
\hline
\end{tabular}

Miscellaneous group include swellings arising from skin, soft tissue, bone, blood vessels, neural tissue, congenital etc. in the region of head and neck.

In $95.67 \%$ cases the quality of aspirate was satisfactory (Figure 1 to 3 )

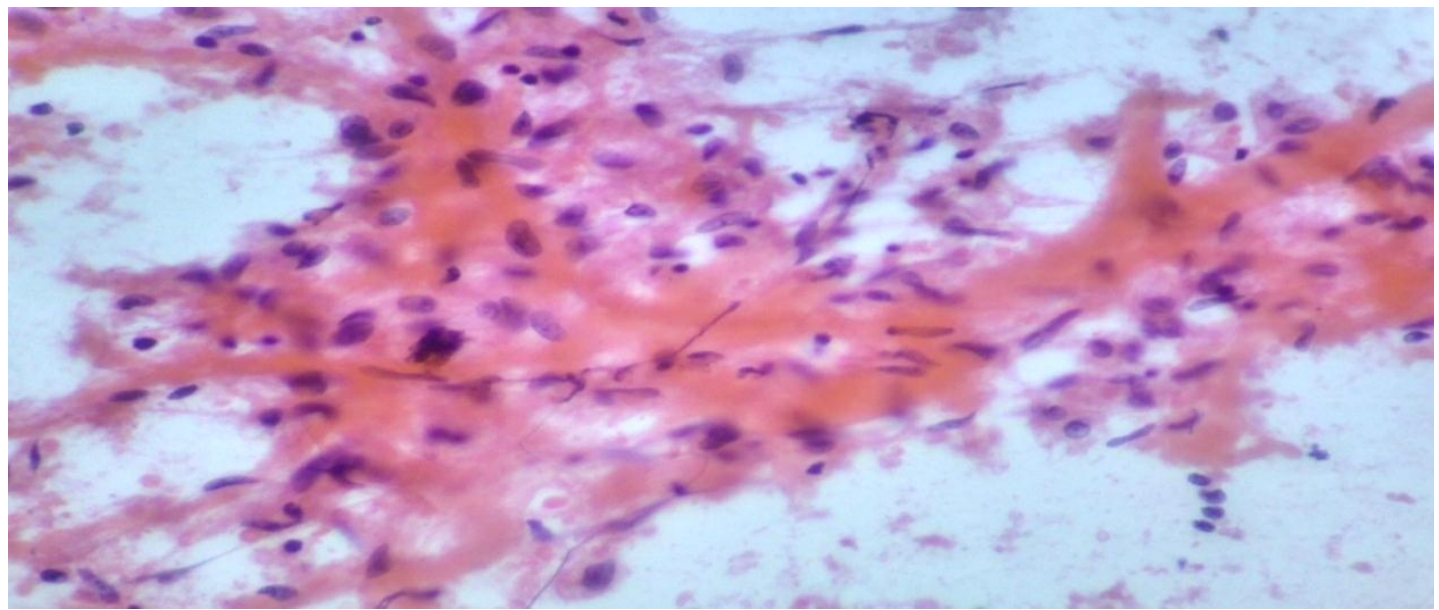

Fig.1:-FNA smear of Tubercular lymphadenitis depicting epithelioid cell granulomas (Pap X 400).

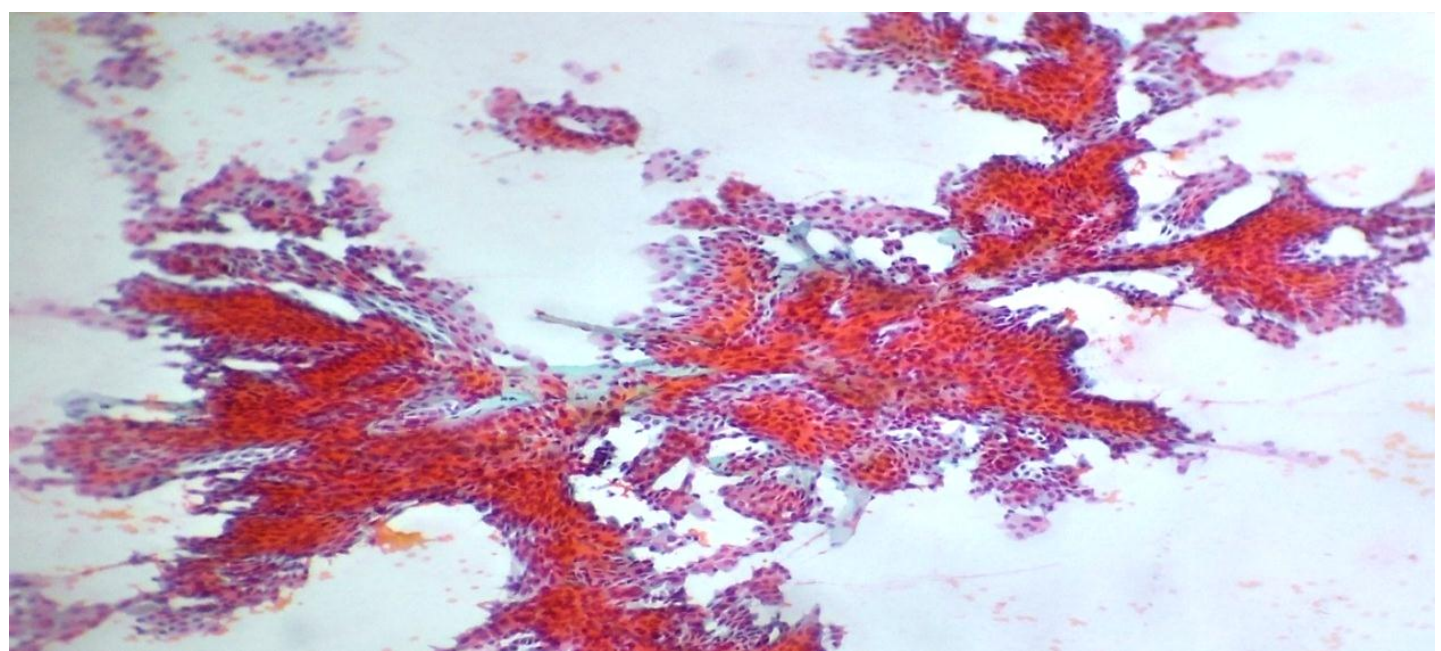

Fig.2:-Papillary Carcinoma Thyroid - Smear showing epithelial cells forming Papillaroid pattern (Pap X 100). 


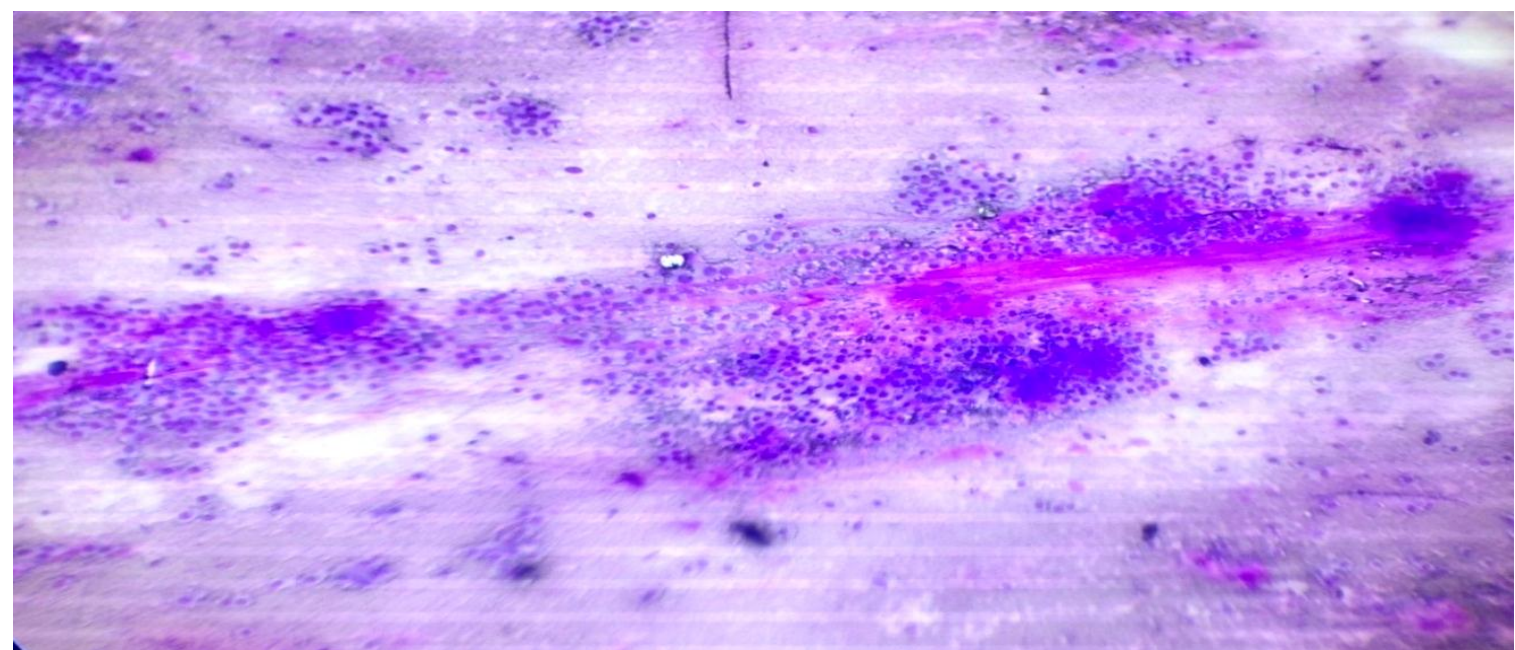

Fig.3:-Pleomorphic Adenoma - FNA smear depicting epithelial and stromal elements (MGG X 100).

In 39(4.33\%) cases the aspirate was unsatisfactory and in all of them no definitive diagnostic opinion could be given. Also in 11(1.28\%) cases inspite of satisfactory aspirate no definitive diagnosis was possible. So overall in the study in $850(94.44 \%)$ cases on FNAC, diagnostic opinion were given and in 50(5.56\%) no diagnosis could be given. Table 2 depicts distribution of cases as per tissue involved and gender.

Table 2:-Gender Distribution as per organ of involvement:

\begin{tabular}{|l|l|l|l|}
\hline Organ of origin & Males & Females & Total \\
\hline Lymph nodes & 260 & 181 & 441 \\
\hline Thyroid Gland & 29 & 146 & 175 \\
\hline Salivary Glands & 41 & 26 & 67 \\
\hline Miscellaneous & 133 & 84 & 217 \\
\hline \multicolumn{1}{|c|}{ Total } & $\mathbf{4 6 3}$ & $\mathbf{4 3 7}$ & $\mathbf{9 0 0}$ \\
\hline
\end{tabular}

Lymphnode involvement (49\%) was the most common. Incidences of lymph node lesion is higher in males while that of thyroid lesion is higher in females. Out of 441 cases of lymphnode lesions, 191 (43.31\%) were having non specific reactive lymphadenitis (Table 3 ).

Table 3:-Cytologic Diagnosis by FNAC in the lymph node group in the study.

\begin{tabular}{|c|c|c|c|c|}
\hline $\begin{array}{l}\text { Organ of } \\
\text { origin }\end{array}$ & Diagnostic Group & Cytologic Diagnosis & $\begin{array}{l}\text { No. of } \\
\text { cases }\end{array}$ & Percentage \\
\hline \multirow[t]{10}{*}{ Lymph node } & \multirow{3}{*}{$\begin{array}{l}\text { Inflammatory and } \\
\text { non neoplastic }\end{array}$} & Reactive Lymphadenitis & 191 & $43.31 \%$ \\
\hline & & $\begin{array}{l}\text { Tubercular Lymphadenitis including } \\
\text { Granulomatous Pathology }\end{array}$ & 125 & $28.34 \%$ \\
\hline & & $\begin{array}{lll}\text { Acute suppurative lymphadenitis } & \text { and } \\
\text { Abscesses } & & \\
\end{array}$ & 30 & $6.80 \%$ \\
\hline & \multirow[t]{6}{*}{ Malignant Tumor } & Metastatic Squamous Cell Carcinoma & 34 & $7.71 \%$ \\
\hline & & Metastatic Adenocarcinoma & 11 & $2.50 \%$ \\
\hline & & Metastatic poorly differentiated Carcinoma & 21 & $4.76 \%$ \\
\hline & & Lymphoma & 12 & $2.72 \%$ \\
\hline & & Metastatic Small Cell Carcinoma & 02 & $0.45 \%$ \\
\hline & & Metastatic Medulloblastoma & 01 & $0.23 \%$ \\
\hline & No Opinion & $\ldots$ & 14 & $3.18 \%$ \\
\hline Total & & & 441 & $100 \%$ \\
\hline
\end{tabular}

Out of 175 cases of thyroid lesions, 153 cases were inflammatory and non neoplastic , 13 cases neoplastic and no opinion was given in 9 cases(Table 4). 
Table 4:-Cytologic Diagnosis by FNAC in Thyroid Gland Group in the study.

\begin{tabular}{|l|l|l|l|l|}
\hline Organ of Origin & Diagnostic Group & Cytologic Diagnosis & $\begin{array}{l}\text { No. of } \\
\text { cases }\end{array}$ & Percentage \\
\hline \multirow{4}{*}{ Thyroid Gland } & \multirow{2}{*}{$\begin{array}{l}\text { Inflammatory and } \\
\text { non neoplastic }\end{array}$} & Colloid Goiter & 93 & $53.14 \%$ \\
\cline { 3 - 5 } & & Lymphocytic Thyroiditis & 42 & $24.00 \%$ \\
\cline { 2 - 5 } & Adenomatous Goiter & 16 & $9.14 \%$ \\
\cline { 2 - 5 } & Granulomatous Thyroiditis & 02 & $1.14 \%$ \\
\cline { 2 - 5 } & \multirow{3}{*}{ Neoplastic lesions } & Follicular Neoplasm & 05 & $2.86 \%$ \\
\cline { 2 - 5 } & & Papillary Carcinoma & 07 & $4.00 \%$ \\
\cline { 2 - 5 } & Anaplastic Carcinoma & 01 & $0.57 \%$ \\
\cline { 2 - 5 } & No Opinion & & 09 & $5.14 \%$ \\
\hline Total & & & $\mathbf{1 7 5}$ & $\mathbf{1 0 0 . 0 0 \%}$ \\
\hline
\end{tabular}

* Including changes like cystic degeneration, hurthle cell change, hyperplastic change.

Salivary gland lesions are depicted in Table 5 .

Table 5:-Cytologic diagnosis by FNAC in Salivary Gland Group.

\begin{tabular}{|c|c|c|c|c|}
\hline Organ of origin & Diagnostic Group & Cytologic Diagnosis & $\begin{array}{l}\text { No. of } \\
\text { cases }\end{array}$ & Percentage \\
\hline \multirow[t]{8}{*}{ Salivary Glands } & \multirow{3}{*}{$\begin{array}{l}\text { Inflammatory and non } \\
\text { neoplastic lesions }\end{array}$} & Sialadenitis & 24 & $35.82 \%$ \\
\hline & & Sialadenosis & 9 & $13.43 \%$ \\
\hline & & Retention cyst & 1 & $1.49 \%$ \\
\hline & \multirow[t]{2}{*}{ Benign tumors } & Pleomorphic Adenoma & 24 & $35.82 \%$ \\
\hline & & Warthin's Tumor & 02 & $2.99 \%$ \\
\hline & \multirow[t]{2}{*}{ Malignant tumors } & Mucoepidermoid Carcinoma & 02 & $2.99 \%$ \\
\hline & & Adeniod Cystic Carcinoma & 02 & $2.99 \%$ \\
\hline & No Opinion & - & 03 & $4.47 \%$ \\
\hline Total & & & 67 & $100 \%$ \\
\hline
\end{tabular}

In the miscellaneous group, most common diagnosis was Epidermal inclusion cyst in 72(33.18\%) cases followed by Lipoma in $49(22.58 \%)$ cases.

\section{Discussion:-}

Fine needle aspiration cytology (FNAC) offers clear advantages. It is minimally invasive, produces a speedy result and is inexpensive. ${ }^{25}$ In the head and neck region, FNAC is of great value because of the multiplicity of accessible organs and heterogenous pathologies encountered. An early differentiation of benign from malignant pathology greatly influences the planned treatment. ${ }^{5}$ The diferential diagnosis of a head and neck swelling covers a broad spectrum of diseases with differing implications for management. The present study was conducted to evaluate the role of FNAC in diagnosing various head and neck lesions. In the present study swellings arising from the head and neck were divided into those arising from lymph nodes, thyroid gland, salivary glands and miscellaneous.

A total of 900 aspirations were performed in patients presenting with head and neck masses. During our experience, we were able to secure adequate tissue by aspiration in about $861(95.67 \%)$ cases. Similar findings have been reported by various authors in literature. ${ }^{10,11,16,30}$ The cytodiagnostic yield was $94.44 \%$ in our study and in $5.56 \%$ of aspirates no diagnosis could be given as the material was unsatisfactory or non representative of the lesion. Such a high comparable diagnostic yield has also been reported by various authors in literature. ${ }^{1,26,27,29}$

In the lymph node group, the most common diagnosis was reactive hyperplasia in $43.31 \%$ cases followed by tubercular lymphadenitis in $28.34 \%$ cases. Similar findings were reported in literature. ${ }^{4,10,17,34}$ In the thyroid gland group, females predominated the study with a $\mathrm{F}: \mathrm{M}=5.03: 1$.Similar female predominance has been reported by various authors in literature. ${ }^{5,10,13,15,17,34}$ Most common diagnosis was colloid goiter and its variants in $62.28 \%$ followed by lymphocytic thyroiditis in $24 \%$ cases. Similar observations have been reported by various authors. ${ }^{5,10,13,15,17,34}$ Papillary Carcinoma was the most common pathology in neoplastic group similar to that reported by various authors. ${ }^{10,33}$ 
In salivary gland group, Parotid gland was most frequently involved. The most common pathology encountered was Sialadenitis $(35.82 \%)$ in non neoplastic category and pleomorphic adenoma $(35.82 \%)$ in neoplastic category. Similar observations are reported in literature. . $^{3,5,6,20}$

In the present study, lesions from miscellaneous tissue origin formed the second largest group.The most common diagnosis encountered was epidermal inclusion cyst,in non neoplastic group. Various authors have reported similar findings in their studies. ${ }^{16,33,34}$ In the neoplastic group, lipoma was the most common diagnosis as also seen in studies conducted by Chauhan et al and Solanki et al.,33

\section{Conclusion:-}

FNAC provides a reliable, cost effective, convenient, easily accessible, non traumatic and highly accurate method for initial workup and management of swellings of head and neck region.The procedure is safe and free from complications and is well tolerated by the patients.

\section{Bibliography:-}

1. Bhagat VM, Tailor HJ, Saini PK, Dudhat RB, Makawana GR, Unjiya RM. Fine needle aspiration cytology in nonthyroidal head and neck masses-A descriptive study in tertiary care hospital. Natl J Med Res 2013; 3(3): 273-6.

2. Cajulis RS, Gokaslan ST, Yu GH, Hidvegi DF. Fine needle aspiration biopsy of the salivary glands. A five year experience with emphasis on diagnostic pitfalls. Acta Cytol 1997; 41(5): 1412-20.

3. Chamyal PC, Sabarigirish K. Clinico-pathological Correlation study of cervical lymph node masses. Indian J Otolaryngol Head Neck Surg 1997; 49(4): 402-5.

4. Chauhan S, Rathod D, Joshi DS. FNAC of swellings of head and neck region. Indian Journal of Applied Basic Medical Sciences 2011; 13(17): 1-6.

5. Cristallini EG, Ascani S, Farabi R, Liberati F, Maccio T, Peciarolo A, et al. Fine needle aspiration biopsy of salivary gland, 1985-1995. Acta Cytol 1997; 41(5): 1421-5.

6. Fernandes H, D' Souza C R S, Thejaswini B N. The role of fine needle aspiration cytology in palpable head and neck masses. JCDR 2009; 3(5): 1719-25.

7. Frable WJ and Frable MA. Thin needle aspiration biopsy. The diagnosis of head and neck tumors revisited. Cancer 1979; 43(4): 1541-8.

8. Gupta G, Joshi DS, Shah A, Gandhi M, Shah NR. FNAC of head and neck swellings. GCSMC J Med Sci 2014; III(I): 38-41.

9. Handa U, Chhabra S, Mohan H. Epidermal Inclusion Cyst: Cytomorphological Features and Differential Diagnosis. Diagn Cytopathol 2008;36(12): 861-3.

10. Jain M, Majumdar DD, Agarwal K, Bais AS, Choudhary M. FNAC as a diagnostic tool in pediatric Head and Neck Lesions. Ind Pediatr 1999; 36: 921-3.

11. Jasani JH, Vaishnani HV, Vekaria PN, Patel D, Shah Y, Savjiani N, et al. Retrospective study of fine needle aspiration cytology of head and neck lesion in tertiary care hospital. IJBAR 2013; 04(04): 253-7.

12. Khandekar MM, Kavatkar AN, Patankar SA, Bagwan IB, Puranik SC, Deshmukh SD. FNAC of salivary gland lesions with histopathological correlation. Ind J Otolaryngol Head Neck Surg 2006; 58(3): 246-8.

13. Kun M. A new instrument for the diagnosis of tumors. Monthly J Med Sci 1847; 7: 853-4.

14. Orell SR, Sterrett GF. Introduction. In: Orell SR, Sterrett GF(Eds). Orell \& Sterrett's Fine Needle Aspiration Cytology, $5^{\text {th }}$ Ed. India, Elsevier; 2012. pp. 1-7.

15. Platt JC, Davidson D, Nelson CL, Weisberger E. Fine needle aspiration biopsy: an analysis of 89 head and neck cases. J Oral Maxillofac Surg 1990; 48 (7): 702-6.

16. Rathod GB, Parmar P. Fine needle aspiration cytology of swellings of head and neck region. Indian J Med Sci 2012; 66(3-4): 49-54.

17. Schelkun PM, Grundy WG. Fine needle aspiration biopsy of head and neck lesions. J Oral Maxillofac Surg 1991; 49(3): 262-7.

18. Schwarz R, Chan NH, MacFarlane JK. Fine needle aspiration cytology in the evaluation of head and neck masses. Am J Surg 1990; 159: 482-5.

19. Solanki PK, Patel AP, Taviad P, Chaudhari VP, Patel SM. Fine Needle Aspiration Cytology as a diagnostic procedure in head and neck swellings. Natl J Community Med 2012; 3(3): 433-6.

20. Taviad DS, Jadav K, Nikhra P, Panchal A, Patel V. Role of fine needle aspiration cytology in head and neck swelling. Int J Res Med 2014; 3(2): 131-4. 